\title{
The Effect of High Carbohydrate Consumption on Glucose Levels and Antibody Production in Nonobese Diabetic Mice
}

\author{
Tonicley Alexandre da Silva, Caio José de Carvalho-Filho, \\ Elizabeth de Sousa Barcelos Barroqueiro, Deysianne Costa das Chagas, \\ Flávia Raquel Fernandes Nascimento, Rosane Nassar Meireles Guerra* \\ Laboratory of Imunophysiology, Universidade Federal do Maranhão, São Luís, Brazil \\ Email: *rnmguerra@pq.cnpq.br, *roguerra@globo.com
}

Received 16 January 2016; accepted 26 August 2016; published 29 August 2016

Copyright (C) 2016 by authors and Scientific Research Publishing Inc.

This work is licensed under the Creative Commons Attribution International License (CC BY). http://creativecommons.org/licenses/by/4.0/

(c) (i) Open Access

\begin{abstract}
The aim of this study was to evaluate the effect of chronic treatment with diets rich in carbohydrates on the IgM and IgG antibody production and the seric glucose concentration in diabetes. Nonobese diabetic (NOD) mice received, ad libitum, by oral route, the diet consisting of an aqueous extract $(20 \mathrm{mg} / \mathrm{mL})$ of the following flours: babassu mesocarp, manioc, corn or rice, during 120 days. The diet intake was monitored throughout this period. At the end, the weight variation, blood glucose, serum IgG and IgM antibody and IgM anti-insulin titers, were determined. The babassu and manioc flour extracts altered Purina chow intake and these animals also presented a significant increase in body weight. In contrast, treatment with rice flour resulted in a significant weight loss. Moderate to severe hyperglycemia was observed in the groups receiving rice and manioc, whereas treatment with babassu mesocarp flour and cornmeal resulted in hypoglycemia. The extracts did not alter the IgG concentration. On the other hand, the cornmeal extract caused a marked reduction in both total IgM and anti-insulin IgM antibody production. Although babassu mesocarp flour, cornmeal and manioc flour caused important variations in the parameters studied, only treatment with the rice flour extract anticipated the onset of diabetes in male mice genetically predisposed to the disease.
\end{abstract}

\section{Keywords}

Carbohydrates, Diabetes, Flour, NOD, Mice, Diet

\footnotetext{
${ }^{*}$ Corresponding author.

How to cite this paper: da Silva, T.A., de Carvalho-Filho, C.J., de Sousa Barcelos Barroqueiro, E., das Chagas, D.C., Nascimento, F.R.F. and Guerra, R.N.M. (2016) The Effect of High Carbohydrate Consumption on Glucose Levels and Antibody Production in Nonobese Diabetic Mice. Food and Nutrition Sciences, 7, 866-873.
} 


\section{Introduction}

The relationship between the ingestion of diets rich in carbohydrates and autoimmunity in mice has been established based on the demonstration that carbohydrates activate self-reactive B lymphocyte clones which increase the production of specific antibodies against self-antigens [1]. Subsequent studies have shown that some types of diet play an important role in the maturation and stimulation of the murine immune system [2].

Carbohydrate is one of the main food sources for the population of the State of Maranhão, Brazil, probably because of its easy access and low cost, since most carbohydrates are present in local or typical products of the Brazilian Northeast. These products include rice flour, cornmeal, manioc flour and babassu mesocarp flour.

Rice (Oryza sativa) flour mainly consists of carbohydrates (80.4\%), followed by protein (6.4\%), fibers (1.6\%), lipids $(0.8 \%)$ and minerals [3]-[5]. In contrast, the main component of cornmeal (Zea mays) is starch (83.6\%), followed by protein (8\% to 11\%) and lipids (3\% to 18\%) [3] [4]. Manioc (Manihot utilissima), also known as macaxeira by the population depending on the region of Brazil, corresponds to the fourth most important energy source worldwide. The main components of manioc flour are carbohydrates (86.4\%), lipids (0.3\%) and protein (1.7\%) [3] [6]. Babassu (Orbignya phalerata) is a native plant species of the Brazilian mid-north. The mesocarp of the fruit of this palm is widely used for infant feeding or as a drug for the treatment of various diseases. The dry powder of the mesocarp mainly consists of carbohydrates (80.3\%), in addition to protein (1.54\%), lipids (0.31\%) and fibers (2.41\%) [7].

The first reports investigating the relationship between the ingestion of diets containing babassu and autoimmunity date back to 1994 [8]. Studying schoolchildren from a certain region in the State of Maranhão, Brazil, it was observed a prevalence of endemic goiter of up to 38\%, although iodine ingestion was adequate. These results were supported by subsequent studies conducted at the Laboratory of Immunophysiology, Federal University of Maranhão, which demonstrated an increase in serum IgM antibodies self-reactive anti-insulin [9] [10], and anti-L-thyroxin [11] in animals treated with babassu flour. Taken together, these results showed an important association between the consumption of babassu and increased self-reactive responses in mice.

Autoantibodies are detected in most autoimmune diseases and therefore serve as prognostic markers of the probability of clinical manifestations and the progression rate of these diseases, and also as diagnostic markers [12].

Nonobese diabetic mice (NOD) are an experimental model of type 1 diabetes, a multigene disease that mainly affects children and young adults and strongly depends on environmental factors such as stress, infection and diet [13] [14]. In NOD mice, the immunophysiological mechanisms underlying the development of diabetes starts with the accumulation of immune cells, macrophages and dendritic cells around the pancreatic islets and ducts immediately after weaning at around 3 weeks of age [15] [16]. Subsequently, $\mathrm{T}$ cells migrate to the pancreas where they accumulate around the ducts and islets. Next, macrophages, dendritic cells and T cells infiltrate the islets, a process resulting in the destruction of beta cells and in the onset of typical symptoms of type 1 diabetes. Generally, female NOD mice, whose islets are infiltrated early, become diabetic earlier (around 3 months of age) and more frequently than male animals. About $80 \%$ of female mice and $40 \%$ of male animals are diabetic by 6 months of age [15] [16].

In view of a sexual dimorphism present in NOD mice and the impact of some environmental factors such as stress, infections and diet, the onset of diabetes can be anticipated or delayed and its clinical course can be aggravated.

Based on the above considerations it was out aim to investigated the effect of chronic consumption of rice, babassu mesocarp, manioc and cornmeal, diets rich in carbohydrates, on the onset of diabetes in NOD mice, evaluating the anti-insulin antibodies and the effect of those treatment on the weight variation, peripheral glucose concentration, and IgM and IgG antibody.

\section{Methods}

\subsection{Animals}

Three-month-old male NOD mice obtained from the Central Animal House of the Federal University of Maranhão (UFMA), São Luís, MA, Brazil, were used.

\subsection{Extract Preparation and Animal Treatment}

The following flours were used to prepare the 4 aqueous extracts, concentration of $20 \mathrm{mg} / \mathrm{mL}$ : Rice, manioc, 
cornmeal and babassu mesocarp. For preparation of the extracts, the flours were weighed and resuspended in sterile distilled water. The mixture was macerated for $6 \mathrm{~h}$ and the extract was filtered through filter paper. The extract yield was determined by incubation of three $1-\mathrm{mL}$ aliquots of each extract at $37^{\circ} \mathrm{C}$ until complete evaporation of the liquid. The extract yield was $9.6 \%$ for babassu mesocarp flour, $10 \%$ for rice flour, $9.5 \%$ for manioc flour, and $8.7 \%$ for cornmeal.

The animals were divided in 5 groups, with 7 animals, each, according the treatment:

Group 1-Control: received only water and Purina chow, during 120 days.

Group 2-Rice: Received, orally, ad libitum, the aqueous extract prepared with rice flour (20 mg/mL) during 120 days.

Group 3-Manioc: Received, orally, ad libitum, the aqueous extract prepared with manioc flour $(20 \mathrm{mg} / \mathrm{mL})$ during 120 days.

Group 4-Cornmeal: Received, orally, ad libitum, the aqueous extract prepared with corn flour (20 mg/mL) during 120 days.

Group 5-Babassu: Received, orally, ad libitum, the aqueous extract prepared with babassu mesocarp flour (20 $\mathrm{mg} / \mathrm{mL}$ ) during 120 days.

The animals were fed with the extracts, orally, ad libitum, during 120 days. During this period it was also have free access to water and mice chow

For the evaluation of individual consumption of diets, water and chow, the animals were housed individually in metabolic cages, during a week.

Weight variations were determined by the difference between initial body weight before treatment and weight measured at $0,30,60,90$, and 120 days.

\subsection{Determination of Blood Glucose}

Glucose was determined before and 30, 60, 90, and 120 days after the beginning of treatment with the extracts. Blood samples were collected from the tip of the tail of the animals. Peripheral blood glucose concentration was assayed with a digital glucose meter (Advantage II, Roche, Brazil) using specific test strips and is expressed as $\mathrm{mg} / \mathrm{dL}$.

\subsection{Concentration of IgM, IgG and IgM-Anti-Insulin Antibody Titers}

Antibody titers were determined by enzyme-linked immunosorbent assay (ELISA) as described previously [17]. The plates were covered with 20 IU insulin for anti-insulin antibody measurement, and with anti-mouse immunoglobulin antibodies (Sigma, USA) for total antibody titration.

\subsection{Statistical Analysis}

The results were analyzed by analysis of variance (ANOVA), followed by the Tukey-Kramer test for multiple comparisons of parametric data and the Kruskal-Wallis test for nonparametric data [18].

\section{Results and Discussion}

No significant differences in diet intake or total ingested fluid volume were observed between the experimental groups (Table 1), although a decrease in water intake was observed in corn, manioc and rice groups. There is an increased intake of mouse food on groups babassu and manioc, but taking into account only the concentration of dietary carbohydrates, one may infer that the animals received a similar glucose supply.

One of the bases of strategies for the prevention of autoimmune diseases, including type 2 diabetes mellitus, is the control and reduction of body weight [19] [20]. Since diets rich in carbohydrates have been associated with weight gain, an increase in body mass index and obesity [21], we investigate the effect of the four types of extracts on the weight variation. These flours were chosen because they are among the products most consumed by the Maranhão population and because all of them have similar carbohydrate content of about $80 \%$.

Analysis of weight variation in NOD mice showed that treatment with babassu and manioc significantly increased the body weight of the animals, especially between day 20 and day 30 of the experiment. The mean body weight of animals of the babassu group was also higher after 50 days of treatment when compared to the control group. In contrast, treatment with cornmeal extract resulted in a marked weight loss (Figure 1(a)). These 
Table 1. Evaluation of the consumption of water, chow and diets rich in carbohydrate babassu mesocarp, corn, manioc and rice, during 120 days, in diabetic NOD mice.

\begin{tabular}{|c|c|c|c|c|}
\hline Treatment & $\begin{array}{l}\text { Water } \\
(\mathrm{mL})\end{array}$ & $\begin{array}{l}\text { Extract } \\
(\mathrm{mL})\end{array}$ & $\begin{array}{l}\text { Total ingested fluid volume } \\
\text { (mL) }\end{array}$ & $\begin{array}{l}\text { Purina chow } \\
\text { (g) }\end{array}$ \\
\hline Control & $4.9 \pm 1.0$ & ------- & $4.9 \pm 1.0$ & $2.7 \pm 0.5$ \\
\hline Babassu & $3.4 \pm 1.2^{1}$ & $3.3 \pm 0.9$ & $7.7 \pm 2.1$ & $3.5 \pm 0.1^{*}$ \\
\hline Corn & $1.9 \pm 0.8^{*}$ & $3.6 \pm 0.6$ & $5.5 \pm 1.4$ & $2.9 \pm 0.8$ \\
\hline Manioc & $2.5 \pm 0.8^{*}$ & $4.5 \pm 1.2$ & $7.0 \pm 2.0$ & $3.8 \pm 0.1^{*}$ \\
\hline Rice & $2.5 \pm 0.4^{*}$ & $3.7 \pm 0.3$ & $6.2 \pm 0.7$ & $3.1 \pm 0.2$ \\
\hline
\end{tabular}

${ }^{1}$ Values are means \pm standard deviation of 5 animals/group evaluated individually for 6 consecutive days. $\left(^{*}\right) P<0.05$ compared to control.

results are in contrast to indications of babassu mesocarp flour for the treatment of obesity and demonstrate that the consumption of both manioc flour and babassu mesocarp flour should be avoided by subjects who are on a weight loss diet, diabetic patients and patients with a predisposition to obesity, especially when considering that weight variations are common in pre-diabetic and diabetic patients due to metabolism defects associated with insulin secretion and/or insulin action [22]. As the carbohydrate content of cornmeal does not differ significantly from the other diets suggests that, even in the absence of direct evidence, components other than carbohydrates exclusively found this diet interfered with the weight variation observed (Figure 1(a)). Another possibility is that body weight gain or loss is associated not only with the concentration but also with the type of dietary carbohydrate. Although not evaluated here, this aspect deserves further investigation.

Consumption of the extracts significantly altered glucose levels when compared to the control group (Figure 1(b)). Babassu and corn groups show a reduction on glucose concentration. Instead, we observed a hyperglycemia on manioc and rice groups. The glucose levels observed in the rice group after 50 days of treatment, was almost the double of the value observed in the control group (Figure 1(b)).

Hyperglycemic diets are risk factors associated with the onset of diabetes due to their effects on the production of glucose and insulin. The main effect includes insulin resistance [23] and hyper-reactivity of pancreatic beta cells [24]. In addition, diets rich in carbohydrates such as those studied here may cause overstimulation of the pancreas by increasing the secretion of contra regulatory hormones and the postprandial free fatty acids [25], glucotoxicity [26], and lipotoxicity through free fatty acids [27]. Therefore, during the development of diabetes chronic hyperglycemia is associated with damage to and dysfunction and failure of various organs, especially eyes, kidneys, nerves, heart and blood vessels. In addition, intervention studies have shown that a better glycemic control permits to delay the occurrence of chronic microvascular complications [28].

One possible explanation for the variations observed in the treated groups might be related to the adaptive capacity of the organism to regulate blood glucose levels through receptor occupation and pre- and/or post-receptor instances [29]. In this case, the overload caused by excessive consumption of carbohydrates may lead to insulin resistance. Insulin resistance is one of the main problems of diabetes control [23]. If insulin resistance occurred in this experiment, it was apparently transitory since glucose levels in the babassu, manioc and cornmeal groups returned to values similar to those of the control group after 60 days of treatment. The same was not observed for the rice group (Figure 1(b)). Thus, the rice extract presented a higher potential of triggering diabetes in genetically predisposed animals when considering the glycemic variations observed in this group, although hypoglycemia resulting from the other treatments may also be a factor predisposing to diabetes. In addition, it should be emphasized that the NOD mice used in the present experiments were males and therefore less prone to the early onset of diabetes [15] [16], since male NOD mice spontaneously develop type 1 diabetes at a low incidence and at an older age than females. About $80 \%$ to $90 \%$ of female mice become diabetic by 6 months of age, whereas this percentage ranges from $40 \%$ to $50 \%$ in male animals at around 9 months of age [29].

Total serum IgM concentration was significantly lower in mice treated with cornmeal or babassu mesocarp after 120 days (Figure 2(a)). These results obtained in NOD mice different to those reported for $\mathrm{C}_{3} \mathrm{H} / \mathrm{HePas}$ [30] mice treated with the same extracts. These differences might be related to the mouse strain used here, since NOD mice presenting peculiarities in terms of the production of total and self-reactive antibodies.

No significant variations in total serum IgG concentration were observed in the animals studied, one possibility is related to the low effect of those diets on the $\mathrm{T}$ cell activation and cytokine production, since genetic alte- 


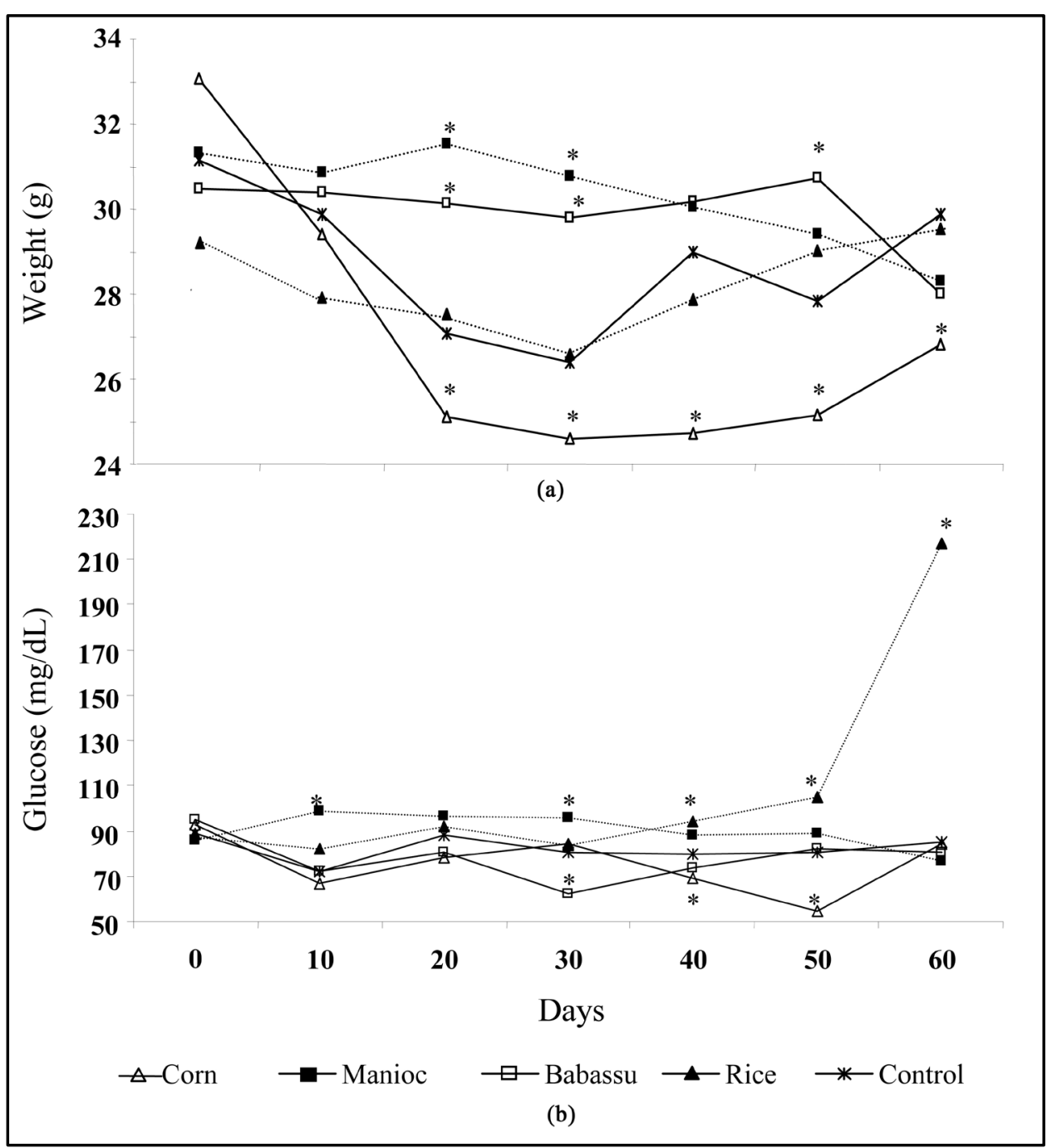

Figure 1. Weight variation (A) and blood glucose concentration (B) in NOD mice receiving an oral diet rich in carbohydrates, ad libitum, during 120 days, consisting of the aqueous extracts of rice, babassu, manioc or cornmeal flour, $20 \mathrm{mg} / \mathrm{mL}$ each. All animals had free access to water and Purina show. Values correspond to the mean \pm standard deviation of 5 animals/group. (*) $P<0.05$ compared to the untreated control group (control).

rations present in these animals may already alter the production of this antibody class. In this respect the normal production of IgG is a good prognostic since the elevated IgG titers related to the expression of FcR receptors is associated with the aggravation of autoimmune diseases as occurs in rheumatoid arthritis [31] and possibly also in diabetes.

In NOD mice, only the treatment with cornmeal decreased the production of anti-insulin IgM, after 120 days of treatment (Figure 2(b)). At the other groups, the anti-insulin production remain unchanged, showing that not only the diet, but other factor may be related the production of self-reactive antibodies in diabetes. In fact, an increased production of self-reactive antibodies is an important prognostic marker of autoimmune diseases, serving as an indicator of the occurrence and progression of diseases such as diabetes [32].

In NOD mice, anti-insulin antibodies mainly belong to the IgG2a class whose synthesis is regulated by the production of IFN- $\gamma$ [33]. This fact may explain the lack of observation of alterations since only anti-insulin IgM antibody titers were quantified. Since the production of antibodies is hardly influenced by T cell activation and the cytokine production, it is reasonable to propose a relation between the carbohydrate content and the cytokine production, although it is the limitation of our study because the production of cytokine was not the scope of this work. 


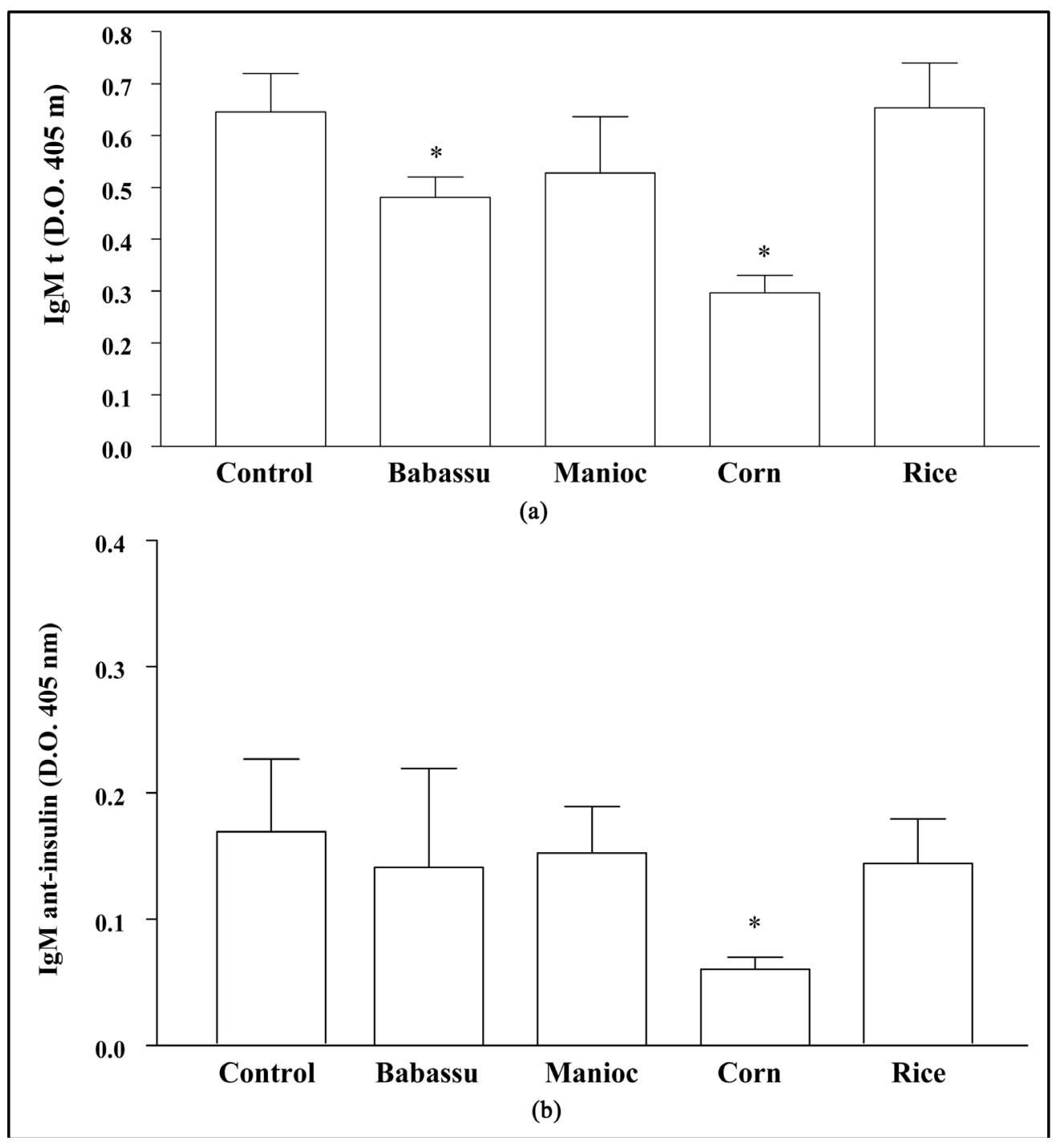

Figure 2. Seric IgM (a) and IgM-anti-insulin (b) titers NOD mice receiving an oral diet, rich in carbohydrates, ad libitum, during 120 days, consisting of the aqueous extracts of rice, babassu, manioc or cornmeal flour, $20 \mathrm{mg} / \mathrm{mL}$ each. All animals had free access to water and Purina show. Values are expressed as the mean \pm standard deviation considering the optical density (OD) of sera diluted $1 / 100$, from 5 animals/group. $\left(^{*}\right) P<0.05$ compared to the untreated control group (control).

\section{Conclusion}

In conclusion, the consumption of diets rich in carbohydrates alters food intake in NOD mice treated with babassu and manioc flour extracts. These extracts caused important variations in body weight and glucose levels, but no differences in total serum IgG concentration were observed. On the other hand, treatment with cornmeal and babassu mesocarp extracts significantly reduced the production of total IgM antibodies. However, only treatment with cornmeal affected the production of anti-insulin IgM antibodies and only the rice extract were able to anticipate the onset of diabetes in mice genetically predisposed to the disease.

\section{Acknowledgements}

To Maranhão State Foundation (FAPEMA), Federal University of Maranhão (UFMA) and National Council for Scientific and Technological Development (CNPq) for the financial support and for the research fellowship of RNMG and FRFN. 


\section{References}

[1] Ogura, M., Ogura, H. and Ikehara, S. (1989) Decrease by Chronic Energy Intake Restriction of Cellular Proliferation in the Intestinal Epithelium and Lymphoid Organs in Autoimmunity Mice. Proceedings of the National Academy of Sciences of the United States of America, 86, 5918-5925. http://dx.doi.org/10.1073/pnas.86.15.5918

[2] Menezes, J.S., Andrade, M.C., Senra, B., Rodrigues, V.S., Vaz, N.M. and Faria, A.M. (2006) Immunological Activities Are Modulated by Enteral Administration of an Elemental Diet in Mice. Clinical Nutrition, 25, 643-652. http://dx.doi.org/10.1016/j.clnu.2006.01.005

[3] Tabela Brasileira de Composição de Alimentos-USP. Version 5.0. [Database on the Internet]. São Paulo (BR): Universidade de São Paulo. Faculdade de Ciências Farmacêuticas. Departamento de Alimentos e Nutrição Experimental/ Brasilfoods. 1998. http://www.fcf.usp.br/tabela

[4] (2015) Composición química y valor nutritivo del maíz. Food and Agriculture Organization, Rome. http://www.fao.org/docrep/T0395S03.htm

[5] Núcleo de estudos e pesquisas; Universidade Estadual de Campinas (2006) Tabela brasileira de composição de alimentos. 2th Edition, Gráfica e Editora Flamboyant Ltda, Campinas.

[6] Montero, W.R. (2002) Cassava: Biology, Production and Utilization. Crop Sciences, 43, 448-454. http://dx.doi.org/10.2135/cropsci2003.4480

[7] Rosenthal, F.R.T. (1975) O amido do coco de babaçu, algumas propriedades dos grânulos e das pastas. Revista Brasileira de Tecnologia, 6, 29-33.

[8] Gaitan, E., Cooksey, R.C., Legan, J., Day, R.H., Ingbar, S.H. and Medeiros-Neto, G. (1994) Antithyroid Effects in Vi$v o$ and in Vitro of Babassu and Manioc: A Staple Food in Goiter Areas of Brazil. European Journal of Endocrynology, 131, 138-144. http://dx.doi.org/10.1530/eje.0.1310138

[9] Guerra, R.N.M., Barroqueiro, E.S.B. and Chagas, A.P. (2001) Increase of Self-Antibodies and Glucose Levels in Mice Treated with Babassu (Orbignya phalerata, Arecaceae [Palmae]). Scandinavian Journal of Immunology, 54, 66.

[10] Barroqueiro, E.S.B., Chagas, A.P., Nascimento, F.R.F. and Guerra, R.N.M. (2001) B cell, Macrophage Activation and the Diabetogenic Effect of Babassu Mesocarp. Revista Brasileira de Medicina Tropical, 34, 72-73.

[11] Barroqueiro, E.S.B., Nascimento, F.R.F. and Guerra, R.N.M. (2002) Efeito do tratamento com mesocarpo de babaçu sobre a produção de anticorpos para o hormônio tireoidiano. Revista do Hospital Universitário-Ufma, 2, 25-27.

[12] Hogarth, P.M. (2002) Fc Receptors Are Major Mediators of Antibody Based Inflammation in Autoimmunity. Current Opinion in Immunology, 14, 798-802. http://dx.doi.org/10.1016/S0952-7915(02)00409-0

[13] Atkinson, M.A. and Eisenbarth, G.S. (2001) Type 1 Diabetes: New Perspectives on Disease Pathogenesis and Treatment. Lancet, 358, 221-229. http://dx.doi.org/10.1016/S0140-6736(01)05415-0

[14] Dahlquist, G.G., Patterson, C. and Soltesz, G. (1999) Perinatal Risk Factors for Childhood Type 1 Diabetes in Europe. The Eurodiab Sub-Study 2-Study Group. Diabetes Care, 22, 1698-1702. http://dx.doi.org/10.2337/diacare.22.10.1698

[15] Jansen, A., Homo-Delarche, F., Hooijkaas, H., Leenen, P.J., Dardenne, M. and Drexhage, H.A. (1994) Immunohistochemical Characterization of Monocytes Macrophages and Dendritic Cells Involved in the Initiation of the Insulitis and Beta-Cell Destruction in NOD Mice. Diabetes, 43, 667-675. http://dx.doi.org/10.2337/diab.43.5.667

[16] Rosmalen, J.G., Leenen, P.J., Pelegri, C., Drexhage, H.A. and Homo-Delarche, F. (2002) Islet Abnormalities in the Pathogenesis of Autoimmune Diabetes. Trends Endocrinology and Metabolism, 13, 209-214. http://dx.doi.org/10.1016/S1043-2760(02)00600-8

[17] Johnstone, A. and Thorpe, R. (1988) “Immunoassays”. In: Johnstone, A. and Thorpe, R., Eds., Immunochemistry in Practice, 2th Edition, Blackwell Scientific Pub, London, 257-260.

[18] Vieira, S. (2003) Bioestatística: Tópicos avançados. Ed. Campus, Rio de Janeiro.

[19] American Diabetes Association (ADA) and National Institute of Diabetes and Digestive (2002) The Prevention or Delay of Type 2 Diabetes. Diabetes Care, 25, 742-749. http://dx.doi.org/10.2337/diacare.25.4.742

[20] Tuomilehto, J., Lindstro, J., Eriksson, J.G., Valle, T.T., Hamalainen, H., Ilanne-Parikka, P., Keinanen-Kiukaanniemi, S., Laakso, M., Louheranta, A., Rastas, M., Salminen, V. and Uusitupa, M. (2001) Prevention of Type 2 Diabetes Mellitus by Changes in Lifestyle among Subjects with Impaired Glucose Tolerance. New England Journal of Medicine, 344, 1343-1350. http://dx.doi.org/10.1056/NEJM200105033441801

[21] Van Baak, M.A. and Astrup, A. (2009) Consumption of Sugars and Body Weight. Obesity Reviews, 10, 9-23. http://dx.doi.org/10.1111/j.1467-789X.2008.00561.x

[22] Gross, J.L., Silveiro, S.P. and Camargo, J.L. (2002) Diabetes Mellitus: Diagnosis, Classification and Glucose Control Evaluation. Brazilian Archives of Endocrinology and Metabolism, 46, 16-26. 
[23] Wood, R.J. and Fernandez, M.L. (2009) Carbohydrate-Restricted versus Low-Glycemic-Index Diets for the Treatment of Insulin Resistance and Metabolic Syndrome. Nutrition Reviews, 67, 179-183. http://dx.doi.org/10.1111/j.1753-4887.2009.00186.x

[24] Poitout, V. and Robertson, R.P. (2008) Glucolipotoxicity: Fuel Excess and Beta-Cell Dysfunction. Endocriny Reviews, 29, 351-366. http://dx.doi.org/10.1210/er.2007-0023

[25] Dedoussis, G.V., Kaliora, A.C. and Panagiotakos, D.B. (2007) Genes, Diet and Type 2 Diabetes Mellitus: A Review. The Review of Diabetic Studies, 4, 13-24. http://dx.doi.org/10.1900/RDS.2007.4.13

[26] Fernandez, E.B. (2007) Glucolipotoxicity, Resistance to the Action of Insulin and Type 2 Diabetes Mellitus. Annals from the Academy National of Medicine, 124, 547-556.

[27] Swaminath, G. (2008) Fatty Acid Binding Receptors and Their Physiological Role in Type 2 Diabetes. Archives of Pharmacy, 341, 753-761. http://dx.doi.org/10.1002/ardp.200800096

[28] Demirtunc, R., Duman, D., Basar, M., Bilgi, M., Teomete, M. and Garip, T. (2009) The Relationship between Glycemic Control and Platelet Activity in Type 2 Diabetes Mellitus. Journal of Diabetes and Its Complications, 23, 89-94. http://dx.doi.org/10.1016/j.jdiacomp.2008.01.006

[29] Ablamunits, V., Elias, D. and Cohen, I.R. (1999) The Pathogenicity of Islet-Infiltrating Lymphocytes in the Non-Obese Diabetic (NOD) Mouse. Clinical and Experimental Immunology, 115, 260-267. http://dx.doi.org/10.1046/j.1365-2249.1999.00802.x

[30] Carvalho-Filho, C.J. (2003) Efeito de dietas ricas em carboidratos sobre a autoimunidade em camundongos. Master Thesis, Universidade Federal do Maranhão-Brazil, São Luís.

[31] Akilesh, S., Petkova, S., Sproule, T.J., Shaffer, D.J., Christianson, G.J. and Roopenian, D. (2004) The MHC Class I-Like Fc Receptor Promotes Humorally Mediated Autoimmune Disease. Journal of Clinical Investigation, 113, 13281333.

[32] Yu, L., Robles, D.T., Abiru, N., Kaur, P., Rewers, M., Kelemen, K. and Eisenbarth, G.S. (2000) Early Expression of Anti-Insulin Autoantibodies of Humans and the NOD Mouse: Evidence Early Determination of Subsequent Diabetes. Proceedings of the National Academy of Sciences of the United States of America, 97, 1701-1706. http://dx.doi.org/10.1073/pnas.040556697

[33] Tian, J., Chau, C. and Kaufman, D.L. (1998) Insulin Selectively Primes Th2 Responses and Induces Regulatory Tolerance to Insulin in Pre-Diabetic Mice. Diabetologia, 41, 237-240. http://dx.doi.org/10.1007/s001250050896

\section{Submit or recommend next manuscript to SCIRP and we will provide best service for you:}

Accepting pre-submission inquiries through Email, Facebook, LinkedIn, Twitter, etc.

A wide selection of journals (inclusive of 9 subjects, more than 200 journals)

Providing 24-hour high-quality service

User-friendly online submission system

Fair and swift peer-review system

Efficient typesetting and proofreading procedure

Display of the result of downloads and visits, as well as the number of cited articles

Maximum dissemination of your research work

Submit your manuscript at: http://papersubmission.scirp.org/ 